\title{
Analisis Ukuran Penyebaran Data (Kemiringan dan Keruncingan) (Studi Kasus:Riwayat Penjualan Usaha Makanan Ibu Apri)
}

\author{
Dzaki Aziz Nugroho', Maulana Firdaus ${ }^{2}$, Hendry Darmawan Ariyanto ${ }^{3}$ \\ 1,2,3 Jurusan Teknologi Informasi, Fakultas Teknologi Informasi, Universitas Bina Sarana \\ Informatika, Indonesia \\ 11dzakiazizofficial@gmail.com, ${ }^{2}$ maufirdaus63@gmail.com, ${ }^{3}$ hendrydarmawan654@ gmail.com
}

\begin{abstract}
Tujuan jurnal ini adalah untuk mencapai pemahaman yang mutakhir tentang Statistika, lebih spesifiknya kemiringan dan keruncingan di dalam Distribusi Data. Di abad ke-21, penggunaan Statistika telah dibuktikan sebagai metode efektif dalam menyusun data untuk mencapai sebuah kesimpulan baik kesimpulan itu diinginkan atau tidak. Distribusi data adalah sebuah daftar yang menunjukan kemungkinan nilai dari sebuah data, distribusi data juga memberitahu seberapa sering sebuah kemungkinan nilai terjadi. Di dalam Statistika, kemiringan juga digunakan untuk mengukur apakah simetri sebuah data. Keruncingan adalah sebuah ukuran dari dua ekor yang digabungkan, keruncingan mengukur jumlah kemungkinan yang ada di ekor. Penggunaan statistika sudah semakin mutakhir di beberapa dekade terakhir, dengan penggunaan komputer dalam membuat statistik, manusia telah mencapai pemahaman yang lebih baik tentang variabel tertentu yang mungkin merupakan penyebab dari sebuah anomali yang dapat memberi manfaat atau merugikan masyarakat manusia.

The purpose of this journal was to achieve proper understanding of Statistics, specifically Skewness and Kurtosis in Data Distribution. In the 21th century, the usage of Statistics has been proven as an effective method of sorting data in order to reach to a certain conclusion whether it is desirable or not. Data distribution is a fuction or listing which shows all the possible values (or intevals) of the data, data distribution also tells you how often each value occurs. In Statistics, Skewness is used to measure the symmetry of data distribution. Kurtosis is a measure of the combined sizes of the two tails, it measures the amount of probability in the tails. The usage of statistics has improved drastically in the recent decades, with the application of computer in creating statistics, human has achieved better understanding about certain variables that may/might be the cause of an anomaly that will benefit or detriment the human society.
\end{abstract}

Keywords : Data distribution, Skewness, Kurtosis, Kemiringan, Keruncingan, Distribusi Data

\section{Pendahuluan}

Distribusi data adalah sebuah fungsi yang menunjukan semua nila dari suatu data dan seberapa sering nilai tersebut terjadi. Ketika distribusi dari data kategorikal divisualkan, kita akan melihat persentasi dari setiap group. Ketika distribusi numerikal divisualkan, kita akan melihat data disusun secara ascending (dari kecil ke besar). Perlu dipahami, distribusi BUKAN hanya tentang grafik. Grafik hanya cara untuk memvisualisasikan. Distribusi seperti definisi diatas, adalah suatu fungsi yang menunjukan probabilitas semua nilai yang mungkin terjadi pada suatu percobaan.

Ukuran keruncingan (kurtosis) adalah derajat kepuncakan dari suatu distribusi data, biasanya diambil relatif terhadap distribusi normal. Ukuran keruncingan adalah ukuran yang digunakan untuk menentukan apakah kepuncakan dari sebuah distribusi data merupakan leptokurtis (lancip), mesokurtis (normal), atau platikurtis (tumpul). Derajat keruncingan distribusi data dapat dihitung berdasarkan rumus yang dispesifikasikan berdasarkan apakah data tersebut berkelompok atau tidak, untuk data tidak berkelompok maka rumus yang dipakai adalah rumus $a_{4}=\frac{1}{n S^{4}} \sum\left(x_{i}-\bar{x}\right)^{4}$, sementara itu jika data berkelompok maka rumus yang digunakan adalah $a_{4}=\frac{1}{n s^{4}} \sum f_{i}\left(m_{i}-\bar{x}\right)^{4}$. Masing-masing rumus memiliki keterangan $\mathrm{a}_{4}=$ derajat keruncingan, $\mathrm{x}_{\mathrm{i}}=$ nilai data $\mathrm{ke}-\mathrm{i}, \mathrm{f}_{\mathrm{i}}=$ frekuensi kelas ke-i, $m_{i}=$ nilai titik tengah kelas ke-i, $\mathrm{S}=$ simpangan baku, $\mathrm{n}=$ banyaknya data. Sifat-sifat keruncingan dapat ditentukan dengan melihat derajat keruncingannya, jika derajat keruncingan memiliki nilai yang sama dengan 3, maka keruncingan data tersebut adalah mesokurtis, jika lebih dari 3, maka keruncingan data tersebut adalah leptokurtis, jika kurang dari 3, maka keruncingan data tersebut adalah platikurtis.

Ukuran kemiringan (skewness) adalah ukuran yang menyatakan suatu model distribusi yang mempunyai derajat kemiringan tertentu. Beberapa kategori distribusi kemiringan dikaitkan dengan ukuran kemiringan positif (ke kanan), kemiringan simetris, dan kemiringan negatif (ke kiri). Ukuran kemiringan dapat ditentukan dengan menggunakan beberapa rumus, rumus Pearson untuk data tidak berkelompok adalah $a=\frac{1}{s}(\bar{x}-\bmod )$ dan untuk data berkelompoknya adalah $a=\frac{3}{s}(\bar{x}-$ med $)$. Rumus momen untuk data berkelompok adalah 
$a_{3}=\frac{1}{n s^{3}} \sum f_{i}\left(m_{i}-\bar{x}\right)^{3}$ dan untuk data tidak berkelompok adalah $a_{3}=\frac{1}{n s^{3}} \sum\left(x_{i}-\bar{x}\right)^{3}$. Rumus Bowley $a=\frac{Q_{3}+Q_{1}-2 Q_{2}}{Q_{3}-Q_{1}}$, rumus Bowley menggunakan nilai kuartil. Sementara itu rumus Pearson dan rumus Momen memiliki keterangan $\mathrm{a}_{3}=$ derajat kemiringan, $\mathrm{x}_{\mathrm{i}}=$ nilai data ke-i, $\bar{x}=$ nilai rata-rata hitung, $\mathrm{f}_{\mathrm{i}}=$ frekuensi kelas $\mathrm{ke}-\mathrm{i}, \mathrm{m}_{\mathrm{i}}=$ nilai titik tengah kelas ke-i, $\mathrm{S}=$ simpangan baku, $\mathrm{n}=$ banyaknya data. Untuk menentukan kemiringan sebuah data, maka dapat dilihat dari derajat kemiringan data tersebut, jika derajat kemiringan memiliki nilai yang sama dengan 0 , maka data tersebut dapat dikatakan simetris, jika data tersebut memiliki nilai kurang dari 0 , maka data tersebut dapat dikatakan miring ke kiri, jika data tersebut memiliki nilai lebih dari 0 , maka data tersebut dapat dikatakan miring ke kanan.

\section{Metode}

Untuk metode yang menggunakan SPSS. Variabel yang ada di distribusi data kami susun dalam satu kolom. Setelah disusun variabel tersebut akan dihighlight. Setelah dihighlight maka kami akan memilih opsi Analyze yang ada di menu di atas panel SPSS. Setelah memilih opsi analyza maka akan muncul drop-down menu. Di opsi dropdown menu kami memilih opsi Descriptive Statistics. Setelah memilih opsi Descriptive Statistics akan muncul lagi opsi drop-down menu. Di opsi drop-down menu kami memilih opsi Frequencies. Setelah memilih opsi Frequencies maka akan muncul panel dan ada 2 box di tengah panel tersebut. Di panel kiri akan muncul kolom variabel dari data yang sudah dihighlight sebelumnya. Pilih opsi variabel tersebut dan klik tombol yang ada di antara box kiri dan kanan. Setelah itu kami memilih menu statistics yang ada di sisi paling kanan panel Frequencies. Setelah menu statistics dipilih, akan muncul lagi panel untuk memilih opsi. Kami akan mencentang opsi Skewness dan Kurtosis. Setelah itu kami akan memilih opsi Continue di bawah panel untuk kembali lagi ke panel Frequencies. Setelah itu kami akan memilih opsi Charts yang ada di kanan panel Frequencies. Akan muncul panel baru. Di panel tersebut, kami mencentang opsi Histograms dan Show normal curve on histogram. Setelah itu kami memilih opsi continue, maka kami akan kembali ke panel Frequencies. Di panel Frequencies, kami memilih opsi OK yang ada di bawah panel. Dengan begitu akan muncul data keruncingan (Kurtosis) dan kemiringan (Skewness), dan histogram dari distribusi data tersebut.

\section{Studi Kasus}

Penjualan Makanan Apri

\begin{tabular}{lc}
\hline \multicolumn{1}{c}{ Jenis Makanan } & Jumlah Terjual \\
Pempek Kapal Selam & 34 \\
Pempek Lenjer & 40 \\
Bolu & 5 \\
Odading & 77 \\
Total & 156 \\
\hline
\end{tabular}

Dengan menggunakan metode yang kami lakukan, maka kami akan mendapatkan nilai kemiringan dan keruncingan beserta histogram dengan sebagai berikut.

\begin{tabular}{|c|c|c|}
\hline \multirow[t]{2}{*}{ N } & Valid & 156 \\
\hline & Missing & 0 \\
\hline \multicolumn{2}{|c|}{ Mean } & 2.8013 \\
\hline \multicolumn{2}{|c|}{ Median } & 3.0000 \\
\hline \multicolumn{2}{|c|}{ Mode } & 4.00 \\
\hline \multicolumn{2}{|c|}{ Skewness } & -.282 \\
\hline \multicolumn{2}{|c|}{ Std. Error of Skewness } & .194 \\
\hline \multicolumn{2}{|c|}{ Kurtosis } & -1.648 \\
\hline \multicolumn{2}{|c|}{ Std. Error of Kurtosis } & .386 \\
\hline
\end{tabular}

Nilai kemiringan dan keruncingan.

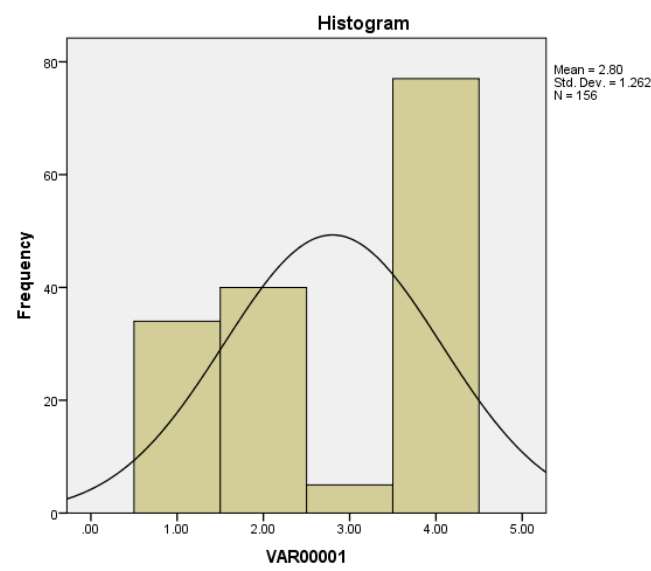

Histogram.

Dari data tersebut, dapat dilihat bahwa mean memiliki nilai 2.8, median memiliki nilai 3 , dan modus memiliki nilai 4, dan kemiringan (skewness) memiliki nilai -0.282. Dari data tersebut, kami dapat menyimpulkan bahwa data tersebut memiliki kemiringan ke arah trend negatif 
atau kemiringan ke arah kiri. Dari data tersebut juga kami dapat menyimpulkan bahwa keruncingan dari distribusi data tersebut bersifat platikurtis.

Untuk metode menggunakan Excel, maka data harus disusun di dalam satu kolom terlebih dahulu, jumlah baris sesuai dengan total variabel data dan data harus disusun. Setelah itu maka pastikan Excel sudah memiliki add-in Analysis Toolpak. Untuk menyalakan Analysis Toolpak maka klik office button yang ada di pojok kiri atas excel, setelah itu klik excel options, setelah itu klik Add-Ins, lalu pilih menu Excel Add-Ins di bagian manage dan klik tombol go, setelah itu centang opsi Analysis Toolpak \& Analysis Toolpak - VBA, lalu klik OK, klik menu Data lalu klik opsi Data analysis, klik Descriptive statistics, masukkan range data di Input range, masukkan lokasi output data di output range, centang Summary statistics lalu klik OK, maka akan muncul tabel data, di tabel data tersebut akan muncul nilai kemiringan (skewness) \& nilai keruncingan (kurtosis). Cara yang lebih sederhana dapat dilakukan dengan cara mengetik rumus $=\mathrm{SKEW}$ (range data) di salah satu sel excel untuk mendapatkan nilai kemiringan, dan mengetik rumus $=$ KURT(range data) di salah satu sel excel untuk mendapatkan nilai keruncingan.

\begin{tabular}{|l|r|}
\hline \multicolumn{2}{|c|}{ Summary Statistics } \\
\hline Mean & 2.801282 \\
\hline Standard Error & 0.101037 \\
\hline Median & 3 \\
\hline Mode & 4 \\
\hline Standard Deviation & 1.261949 \\
\hline Sample Variance & 1.592514 \\
\hline Kurtosis & -1.64842 \\
\hline Skewness & -0.28169 \\
\hline Range & 3 \\
\hline Minimum & 1 \\
\hline Maximum & 4 \\
\hline Sum & 437 \\
\hline Count & 156 \\
\hline
\end{tabular}

Output data yang menggunakan Add-Ins. Keruncingan $==$ =KURT (A1:A156) Kemiringan $=$ =SKEW $($ A1:A156)

Rumus Excel tanpa menggunakan Add-Ins.

\begin{tabular}{|r|r|}
\hline Keruncingan $=$ & -1.64842 \\
\hline Kemiringan $=$ & -0.28169 \\
\hline
\end{tabular}

Untuk membuat histogram di dalam Excel klik opsi Data lalu klik opsi Data analysis, pilih opsi histogram lalu klik OK, masukkan input range data anda, lalu masukkan lokasi dimana output data anda akan keluar, centang opsi chart output lalu klik OK, histogram akan muncul.

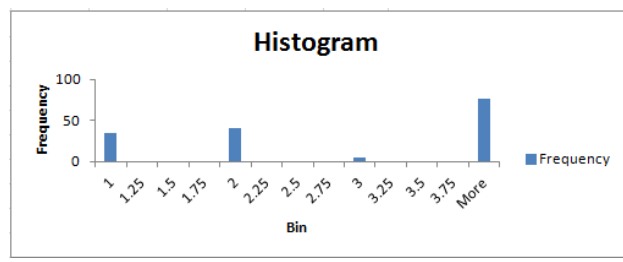

Histogram pada Excel.

\section{Perbandingan}

Untuk perbandingan output data antara Excel dan SPSS dengan perhitungan menggunakan koefisien pearson maka akan diperoleh dengan cara sebagai berikut:

$$
a=\frac{3}{1,26}(2,8-3)
$$

1.26 merupakan nilai dari standar deviasi, 2.8 merpakan nilai rata-rata, 3 yang berada di dalam kurung merupakan nilai dari median, dan 3 yang merupakan penyebut berasal dari rumus koefisien pearson untuk data berkelompok, dari perhitungan tersebut kami memperoleh nilai -0.47619 sebagai kemiringan.

Kami akan menggunakan perbandingan yang sama terhadap keruncingan dengan menggunakan rumus yang sesuai untuk keruncingan.

$$
a_{4}=\frac{1}{393.19} \sum 5(3-2.8)^{4}
$$

5 merupakan nilai frekuensi kelas ke-3, 3 merupakan nilai titik tengah kelas ke-3, 2.8 merupakan nilai, 393.19 merupakan hasil dari banyaknya data dikalikan simpangan baku berpangkat 4 sesuai rumus. Dari hasil perhitungan, kami mendapatkan nilai keruncingan sebesar 0.00002 . 


\section{$5 \quad$ Kesimpulan}

Berdasarkan perbandingan data yang kami dapatkan melalui metode Excel, SPSS, dan perhitungan sesuai rumus, kami memperoleh nilai yang berbeda antara Excel dan SPSS dengan perhitungan sesuai dengan rumus, nilai yang didapatkan dari Excel dan SPSS adalah -1.648 untuk keruncingan dan -0.28 untuk kemiringan sementara itu, berdasarkan perhitungan sesuai dengan rumus koefisien pearson, nilai kemiringan yang kami dapatkan adalah -0.47619 , dan untuk nilai kurtosis, kami mendapatkan nilai 0.00002 . Meskipun hasil yang didapatkan antara Excel dan SPSS dengan perhitungan sesuai rumus berbeda, nilai ini masih berada di dalam area aturan yang sama, nilai keruncingan yang kurang dari angka 3 membuktikan bahwa nilai kurtosis dari distribusi data dapat dikategorikan sebagai platikurtis, dan nilai kemiringan yang kurang dari 0 membuktikan bahwa kemiringan distribusi data dikategorikan sebagai kemiringan negatif atau miring ke kiri.

\section{Daftar Pustaka}

Sofyani, H. (2019, September 25). Pertemuan 5: UKURAN PENYEBARAN. Retrieved November 8 , 2020, from Slide Player: https://slideplayer.info/slide/3791471 